Historic, Archive Document

Do not assume content reflects current scientific knowledge, policies, or practices. 



\section{Single Comb Rhode Island Red Poultry}

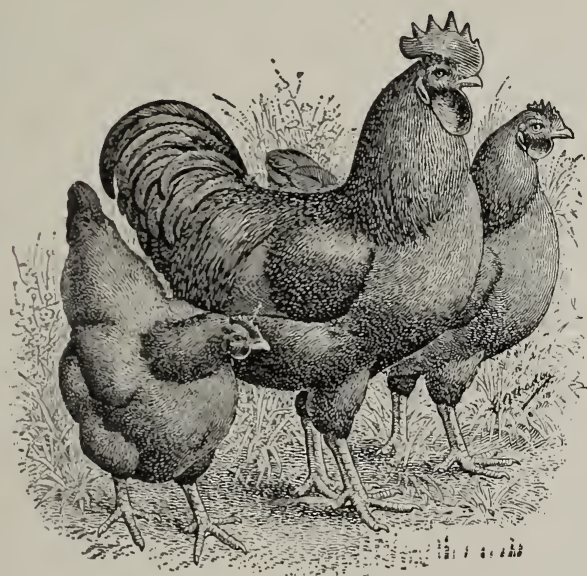

Another season growing R. I. Reds has fully convinced me that they are the most profitable, the hardiest, the most prolific and the only real practical, pure bred fowl now in the standard.

If you are a lover of poultry, why not grow thoroughbred, and a strain that is not only beautiful to look at but without a doubt the most profitable. R. I. Reds are rapidly pushing their way to the front, a position which they justly deserve, and many breeders of fancy birds have discarded all others and are growing Reds exclusively as they are considered better suited to the needs of most people. They are beyond a doubt the best all around greneral purpose fowl. They are the hardiest of all breeds, being less liable to colds and roup than any other. The hens are the best of mothers, not always broody, small eaters and splendid foragers. The males weigh from $71 / 2$ to $81 / 21 \mathrm{bs}$, the females from 5 to $6 \frac{1}{2}$ lbs. They have plump, meaty bodies, make rapid growth, are fine broilers and are desirable at any age for the table. Pullets mature early, lay in five months and cannot be beaten for winter layers. The Reds have records of $255 \mathrm{eggs}$ in twelve months as pullets.

To all who want beautiful fowl and great egg producers I unhesitatingly recommend Single Comb Rhode Island Reds.

My foundation stock came from the best breeders in the country, being carefully bred for years and I honestly believe there is no better birds to be had anywhere, at any price than what I have in my egg producing pens, and which are fertilized with handsome, vigorous cockerels, that if exhibited I am sure would receive the highest awards. I breed only Single Comb Rhode Island Reds and there is no possible chance of a mixture of breeds. The Reds are good enough for me and I want no others.

I have no birds for sale, nothing but eggs, which I guarantee to be strictly fresh, and from my own thoroughbred stock, carefully packed and delivered to Adams Express Office here.

Price, $\$ 1.50$ per $15 ; \$ 2.50$ per 30 .

\section{T. E. Steele, Palmyra, New Jersey}

Atlantic City, N. J., March 16, 1909.

Your R. I. Red eggs are all right. We hatched out the whole 29, lost none only the one broken in shipment.

EDWIN SMITH. 
